\title{
Verbal behavior in Alzheimer disease patients Analysis of phrase repetition
}

\author{
Juliana Francisca Cecato ${ }^{1}$, José Eduardo Martinellit', Luana Luz Bartholomeu, \\ Ana Paula Basqueira ${ }^{4}$, Mônica Sanches Yassuda ${ }^{5}$, Ivan Aprahamian ${ }^{6}$
}

\begin{abstract}
Language problems in the elderly with $\mathrm{AD}$ are due to the fact that deterioration occurs not only in semantic memory, but in a group of cognitive factors, evidenced by a deficiency in search strategies for linguistic information. Objectives: To evaluate phrase repetition in two cognitive tests, the MMSE and MoCA, in a group of Alzheimer disease patients (AD) and normal controls. Methods: A Cross-sectional study was conducted involving 20 patients who sought medical assistance at a geriatric institute in Jundiaí, São Paulo. The subjects underwent a detailed clinical examination and neuropsychometric evaluation. All subjects with AD met DSM-IV and NINCDS-ADRDA criteria. Ten patients received a diagnosis of AD and 10 were healthy subjects, forming the control group (CG). Results: All participants correctly answered the phrase from the MMSE (phrase 1). The MoCA phrases (phrases 2 and 3) were correct in $80 \%$ and $90 \%$, respectively in the CG and in $40 \%$ and $50 \%$, respectively in the AD group. Conclusions: The MoCA test proved more effective in evaluating the echoic behavior in AD patients compared to the MMSE. The simpler phrase repetition task in the MMSE was found to be less sensitive in detecting mild language decline in $\mathrm{AD}$ patients.
\end{abstract}

Key words: verbal behavior, elderly, Alzheimer's disease, language, cognitive tests.

\section{Comportamento verbal em pacientes com doença de Alzheimer: análise da repetição de frases}

Resumo - As dificuldades com a linguagem em idosos com Alzheimer (DA) se devem ao fato de que a deterioração não está relacionada apenas à memória semântica, mas um conjunto de fatores cognitivos, os quais demonstram a deficiência nas estratégias de busca de informações lingüísticas. Objetivos: Avaliar a repetição de frases em dois testes cognitivos (MEEM e MoCA), em um grupo de participantes normais e outro com o diagnóstico de DA. Métodos: Estudo transversal com 20 pacientes que procuraram o serviço de saúdo no instituto de geriatria em Jundiaí, São Paulo. Os participantes passaram por anamnese clínica detalhada e avaliação neuropsicométrica. O grupo de participantes com diagnóstico de DA foi feito pelos critérios do DSM-IV e NINCDS-ADRDA. Dez pacientes receberam o diagnóstico de DA e 10 como participantes normais, formando o grupo controle (GC). Resultados: Todos os participantes responderam corretamente a frase do MEEM. As frases do MoCA (frase 2 e 3 ) foram corretas em $80 \%$ e $90 \%$ respectivamente no GC. O grupo com DA respondeu corretamente $40 \%$ e 50\% respectivamente. Conclusões: O teste MoCA mostrou ser mais eficiente em avaliar o comportamento verbal ecóico em pacientes com DA quando comparados ao MEEM. A simples repetição de frase no MEEM mostrou ser menos sensível para detectar declínio leve de linguagem em pacientes com DA.

Palavras-chave: comportamento verbal, idosos, doença de Alzheimer, linguagem, testes cognitivos.

Verbal behavior is a complex operating behavior which is maintained by listener's feedback in such a way that both subjects have similar verbal repertoire, trained naturally by the environment. ${ }^{1-4}$ It has special operant characteristics, as it has an indirect and non-mechanical influence with the physical environment. Nevertheless, its effects directly change human behavior through the relationship with other subjects. ${ }^{1-4}$

${ }^{1}$ Instituto de Geriatria e Gerontologia de Jundiaí e Faculdade Anhanguera de Jundiaí, Jundiaí SP, Brazil. ${ }^{2}$ Instituto de Geriatria e Gerontologia de Jundiaí

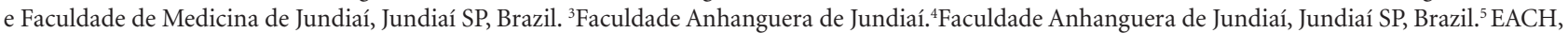
Universidade de São Paulo, São Paulo SP, Brazil. ${ }^{6} I P q$ HCFMUSP e Hospital Albert Einstein, São Paulo SP, Brazil.

Juliana Francisca Cecato - Rua Prudente de Moraes, 111 - 13201-004 Jundiaí SP - Brazil. E-mail: cecatojuliana@hotmail.com

Disclosure: The authors report no conflicts of interest.

Received March 31, 2010. Accepted in final form July 12, 2010. 
In the elderly, verbal behavior and the linguistic abilities receive greater attention due to their sensitivity in the diagnostic investigation of dementia. ${ }^{5,6}$ Language disorders emerge frequently in dementias. ${ }^{7}$ The incidence of language difficulties in dementia syndromes ranges from 88 to $95 \%$ and in the case of Alzheimer' disease (AD), these communication disturbances may afflict $100 \%$ of patients. ${ }^{5}$

Verbal behavior deficits in the elderly are frequently interpretated as symptoms of dementia. ${ }^{7}$ Along these lines, Amieva et al. ${ }^{8}$ found that healthy subjects who evolved to $\mathrm{AD}$ presented language decline on objective verbal fluency tasks twelve years before the diagnosis.

Syntactic complexity seems to be reduced in patients with dementia compared with elderly healthy subjects as is formulation of short phrases, while impaired syntactic comprehension are also characterized. ${ }^{9}$ Some language functions remain preserved in the earlier stages of dementia such as comprehension, syntax and repetition of phrases. ${ }^{7,10}$ The language problems in the elderly with $\mathrm{AD}$ are due to the fact that deterioration occurs not only in semantic memory, but in a group of cognitive factors. This deficiency is evidenced by the search strategies used for linguistic information. ${ }^{7,10}$ In a 1987 study, the Alzheimer group score was worse in phrase repetition compared with healthy elderly subjects. Nevertheless, both groups (normal controls and $\mathrm{AD}$ group) had the same score on other cognitive tests. ${ }^{11}$

In a review, Benke et al. ${ }^{7}$ described that cognitive evaluations may not be effective for understanding how language deficits work in dementia and aphasias. In the elderly, the neuropsychological tests should evaluate several domains including speech, naming, repetition and several others, to reach an effective differential diagnosis in cases of aphasia and dementia. ${ }^{7,10,12}$

The aim of this paper was to evaluate the echoic verbal behavior in the phrase repetition test from two cognitive instruments, the Mini-Mental State Examination $(\mathrm{MMSE})^{13}$ and Montreal Cognitive Assessment (MoCA), ${ }^{14}$ in a group of $\mathrm{AD}$ patients and normal controls.

\section{Methods}

A cross-sectional study involving 20 patients who sought medical assistance at a geriatric institute in Jundiaí, São Paulo was conducted between January 2009 and January 2010. The subjects underwent a detailed clinical examination and neuropsychometric evaluation. The tasks used were: the CAMDEX and its cognitive battery (CAMCOG) ${ }_{,}^{15}$ MMSE, ${ }^{13}$ verbal fluency with animals, fruits and words with the letter " $\mathrm{M}$ " versions, ${ }^{6,16}$ Clock Drawing test, ${ }^{17}$ Geriatric Depression Scale (GDS) ${ }^{18}$ and the MoCA test - Brazilian version. ${ }^{14}$ All tasks were applied as part of the routine local neuropsychological evaluation of patients with complaints of cognitive decline. $\mathrm{AD}$ patients with severe cognitive decline (Clinical Dementia Rating $\geq 3$ ), major depression, plegia or paresis, important tremor, functional impairment in both hands, severe visual or auditory impairment, and patients who refused to complete any of the tests, were excluded. All subjects with AD met DSM-IV ${ }^{19}$ and NINCDSADRDA criteria for probable AD. ${ }^{20}$ Inclusion criteria for the control group were neuropsychiatric tests scores above the cut-off points, without dementia criteria on DSM-IV, a GDS score lower than seven points and absence of functional impairments in daily living activities as informed by a relative or caregiver. The subjects were matched for education level. None of the patients were in use of any drug that potentially depresses the central nervous system at the time of the neuropsychological evaluation.

Ten patients received diagnosis of $\mathrm{AD}$ and 10 as healthy subjects, forming the control group (CG). Subjects in both groups were aged 60 years or older and had more than 8 years of formal education. The evaluations were carried out after the first clinical examination and the patients did not take any medication. All information were analyzed by the SAS System for Windows (Statistical Analysis System) 6.12 version and SPSS 15.0 (2007). To describe the profile of the sample, frequencies of categorical variables (gender and education) and descriptive statistics of continuous variables (age, scores from CAMCOG, MMSE and MoCA), the mean values, standard deviation, minimum, maximum and median were presented. Spearman's coeficient was used to correlate the tests with the phrases from the MMSE (phrase 1) and from the MoCA (phrase 2 and 3). The independent samples test (T-test) was used to evaluate means and the significant differences among the tests. The phrases were: phrase $1=$ "Nem aqui, nem ali, nem lá"; phrase 2="Eu somente sei que é João quem será ajudado hoje"; phrase $3=$ "O gato sempre se esconde embaixo do sofá quando o cachorro está na sala”.

\section{Results}

Of the 20 subjects, 13 (65\%) were women. In the $\mathrm{AD}$ group, the age range was 65 to 91 years old (mean $=76.7$ yrs, median $=76.5 \mathrm{yrs}$, standard deviation $[\mathrm{SD}]= \pm 7.45 \mathrm{yrs}$ ) and 10 participants had high educational level ( $>8$ years). Mean age in the CG was 68.8 years old, $(\mathrm{SD} \pm 4.66 \mathrm{yrs})$. All participants in the CG had high educational levels.

In $\mathrm{AD}$ group, 9 subjects did not achieve the cut-off on the MMSE ( mean=23.9, median $=24, \mathrm{SD} \pm 3.98$ ) and none achieved this score on the MoCA (mean=19.7 median=21, $\mathrm{SD} \pm 3.74$ ). On the CAMCOG battery (mean $=78.5$, median $=81, S D=11.32), 60 \%$ scored above the cut-off. The CG had high scores on the MMSE, MoCA and the CAMCOG (Table 1). 
Table 1. Scores of 20 subjects on cognitive tests.

\begin{tabular}{lcccccc}
\hline Tests & Group & N & Mean & Min. & Max. & SD \\
\hline MMSE & AD & 10 & 23.9 & 15 & 28 & 3.98 \\
\multirow{2}{*}{ CAMCOG } & CG & 10 & 29.5 & 29 & 30 & 0.53 \\
& AD & 10 & 78.5 & 60 & 95 & 11.32 \\
MoCA & CG & 10 & 100.2 & 93 & 107 & 4.59 \\
& AD & 10 & 19.7 & 12 & 23 & 3.74 \\
& CG & 10 & 27.9 & 26 & 30 & 1.45 \\
\hline
\end{tabular}

AD: Alzheimer's disease group; CG: control group; N: number of subjects; Min: minimum; Max: maximum; SD: standard deviation.

Table 2. T-test analyses of cognitive evaluations, age and education in 20 subjects by CG and AD.

\begin{tabular}{|c|c|c|c|c|c|c|}
\hline & Groups & $\mathbf{N}$ & Mean & SD & Mean Std.Error & Sig. (2-tailed) \\
\hline \multirow[t]{2}{*}{ MoCA score } & $\mathrm{AD}$ & 10 & 19.90 & 3.872 & 1.224 & $<0.001$ \\
\hline & CG & 10 & 27.90 & 1.449 & 0.458 & \\
\hline \multirow[t]{2}{*}{ MMSE score } & $\mathrm{AD}$ & 10 & 23.80 & 3.910 & 1.236 & $<0.001$ \\
\hline & CG & 10 & 29.50 & 0.527 & 0.167 & \\
\hline \multirow[t]{2}{*}{ CAMCOG } & $\mathrm{AD}$ & 10 & 79.40 & 11.965 & 3.784 & $<0.001$ \\
\hline & CG & 10 & 100.20 & 4.590 & 1.451 & \\
\hline \multirow[t]{2}{*}{ Mendez } & $\mathrm{AD}$ & 10 & 18.30 & 2.406 & 0.761 & 0.148 \\
\hline & CG & 10 & 19.50 & 0.707 & 0.224 & \\
\hline \multirow[t]{2}{*}{ Shulman } & $\mathrm{AD}$ & 10 & 4.20 & 0.789 & 0.249 & 0.105 \\
\hline & CG & 10 & 4.70 & 0.483 & 0.153 & \\
\hline \multirow[t]{2}{*}{ Sunderland } & $\mathrm{AD}$ & 10 & 9.10 & 1.912 & 0.605 & 0.154 \\
\hline & CG & 10 & 10.00 & 0.000 & 0.000 & \\
\hline \multirow[t]{2}{*}{ VF Animals } & $\mathrm{AD}$ & 10 & 10.30 & 4.900 & 1.550 & $<0.001$ \\
\hline & CG & 10 & 18.70 & 3.592 & 1.136 & \\
\hline \multirow[t]{2}{*}{ VF Fruits } & $\mathrm{AD}$ & 10 & 7.80 & 1.814 & 0.573 & $<0.001$ \\
\hline & CG & 10 & 16.40 & 3.688 & 1.166 & \\
\hline \multirow[t]{2}{*}{ VF“M” } & $\mathrm{AD}$ & 10 & 8.70 & 4.990 & 1.578 & 0.011 \\
\hline & CG & 10 & 14.50 & 4.062 & 1.285 & \\
\hline
\end{tabular}

AD: Alzheimer's disease; CG: control group; N: number of subjects; VF: verbal fluency.

Analyses of the T-test results discriminated the two groups: $\mathrm{AD}$ and CG. This analysis showed that the mean in the $\mathrm{CG}$ was higher than that in the $\mathrm{AD}$ group on the MoCA $(\mathrm{p}<0.001)$, MMSE $(\mathrm{p}<0.001)$, CAMCOG $(\mathrm{p}<0.001)$, verbal fluency test animals $(\mathrm{p}<0.001)$, fruits $(\mathrm{p}<0.001)$, letter " $\mathrm{M}$ " $(\mathrm{p}=0.011)$ and age $(\mathrm{p}<0.001)$ (Table 2$)$.

Comparing the repetition of phrases task, all 20 subjects (AD and CG) repeated the sentence correctly on the MMSE (phrase 1). On the MoCA, 6 patients in the $\mathrm{AD}$ group failed to repeat the first phrase (phrase 2) and 5 failed to repeat the second sentence (phrase 3). Despite failing to repeat the MoCA phrases, these subjects successfully repeated the MMSE phrase (Table 3).

All participants from the CG correctly repeated the MMSE phrase (100\%). The MoCA phrases (phrases 2 and 3) were correct in $80 \%$ and $90 \%$ (respectively) in the CG.
The AD group underperformed on the MoCA showing worse scores compared to those of the CG (Table 3).

\section{Discussion}

This study compared phrase repetition in the MMSE and MoCA tests. On the MMSE, both groups successfully performed the language task of phrase repetition, but differed significantly compared to the MoCA. These findings can be explained by the fact that some aspects of language, such as the repetition of simple phrases (MMSE phrase) appear to be preserved in early and moderate stages of dementia. ${ }^{21}$ However, our findings showed that the more complex the sentence, the greater difficulty dementia patients have repeating them. These outcomes corroborate those of Knibb's studies that found linguistic impairment in dementia. In tasks which required understanding of the 
Table 3. Scores of both groups on repetition phrases of the MMSE and MoCA.

\begin{tabular}{llccc}
\hline Subjects & Answer & Phrase 1 n (\%) & Phrase 2 n (\%) & Phrase 3 n (\%) \\
\hline $\mathrm{AD}$ & Correct & $10(100 \%)$ & $4(40 \%)$ & $5(50 \%)$ \\
& Error & 0 & $6(60 \%)$ & $5(50 \%)$ \\
\multirow{2}{*}{ CG } & Correct & $10(100 \%)$ & $8(80 \%)$ & $9(90 \%)$ \\
& Error & 0 & $2(20 \%)$ & $1(10 \%)$ \\
\hline
\end{tabular}

n: numbers of subjects.

meaning of the phrase, ${ }^{5}$ as observed in MoCA, AD patients had a worse score compared to controls. Similar results were found by Murdoch ${ }^{11}$ and recently by Báez et al. ${ }^{22}$ who assessed the performance of $\mathrm{AD}$ patients on tasks involving the interpretation of word meaning. In their sample of 60 subjects, patients with $\mathrm{AD}$ were found to have considerable difficulty in semantics.

The MoCA test seems to be a more robust instrument compared to the MMSE because it involves more words in the phrase repetition test, little evidence of learning and a long delay before word recall, ${ }^{23}$ explaining the worse performance in verbal behavior on the repetition of phrases. The complex phrases should be used for differentiating cases of dementia ${ }^{7}$ and healthy elderly with high education, because performance on language tests such as repeating complex phrases appears to be impaired in cases of Alzheimer's disease.

Another important concern is with regard to levels of education. Less educated subjects can be at a higher risk for $\mathrm{AD} .{ }^{24}$ The participants in this study had high levels of schooling, which showed the importance of education in the preservation of cognitive functions objectively assessed in the CAMCOG evaluation. ${ }^{25}$ High scores on the CAMCOG were reported by Aprahamian et al. ${ }^{26}$ whose study found new cut-off points on the CAMCOG test according to education. In subjects with a high level of education ( $\geq 9$ years) the cut-off point should be 90 points. In comparison, the mean score found in our $\mathrm{AD}$ group was 78.5, i.e. well below the score proposed by Aprahamian et al. while our control group had a mean score of 100.2.

Level of education should be considered in psychological evaluations because it can generate false positives in patients with low educational levels and false negatives in highly educated individuals. ${ }^{27}$ Another concern is regarding the capacity to concentrate in dementia patients.

To conclude, the MoCA phrase repetition test proved more effective in evaluating the echoic behavior in AD patients compared to the MMSE phrase. The simpler phrase repetition task on the MMSE was found to be less sensitive in detecting mild language decline in $\mathrm{AD}$ patients.

These results suggest that verbal behavior is a complex skill in the evaluation of dementia and is subject to en- vironmental influences such as education. Findings also suggest that future studies, involving a large number of participants, are needed to investigate subtle linguistic changes in $\mathrm{AD}$ patients.

\section{References}

1. Matos MA. As categorias formais de comportamento verbal em Skinner. Texto publicado nos Anais da XXI Reunião Anual da Sociedade de Psicologia de Ribeirão Preto, 1991:333-341.

2. Barros RS. Uma introdução ao comportamento verbal. Rev Bras de Ter Comp Cogn 2003;V(1):73-82.

3. Sério TMAP, Andery MA, Gioia OS, et al. Comportamento verbal. In.: Controle de estímulos e comportamento operante. São Paulo, Educ; 2008;203:127-152.

4. Martin G, Pear J. Motivação e modificação de comportamento. In: Garry M, Pear J (Editors). Modificação de comportamento: o que é e como fazer. Ed. Roca, $8^{\text {a }}$ edição. São Paulo SP; 2009;544:278-288.

5. Mac-Kay APMG. Comunicação, fala e linguagem nas demências. CEFAC, 2003.

6. Caramelli P, Carthery MT, Porto CS, et al. Teste de fluência verbal no diagnóstico da doença de Alzheimer leve: notas de corte em função da escolaridade. Arq Neuropsiquiatr 2003;61(suppl 2):32.

7. Benke T, Andree B, Hittmair M, et al. Speech changes in dementia. Fortschr Neurol Psychiatr; 1990;58:215-223.

8. Amieva H, Goff ML, Millet X, et al. Prodromal Alzheimer's disease: successive emergence of the clinical symptoms. Ann Neurol 2008;64:492-498.

9. Knibb JA, Woollams AM, Hodges JR, et al. Making sense of progressive non-fluent aphasia: an analysis of conversational speech. Brain 2009;132:2734-2746.

10. Teixeira AL, Caramelli P. Neuropsicologia das demências. In: Fuentes D, Malloy-Diniz L, Camargo CP, Cosenza RM (Editors). Neuropsicologia: teoria e prática. Porto Alegre: Artmed; 2008;430:356-363.

11. Murdoch BE, Chenery HJ, Wilks V, et al. Language disorders in dementia of the Alzheimer type. Brain Lang 1987;31:122-137.

12. Ávila R, Bottino CMC. Avaliação neuropsicológica das demências. In: Fuentes D, Malloy-Diniz LC, Pires C, Cosenza RM. Neuropsicologia: teoria e prática. Porto Alegre: Artmed; 2008;430:364-380. 
13. Folstein MF, Folstein SE, Mchugh PR. "Mini Mental state”. A practical method for rading the cognitive state of patients for the clinician. J Psychiatr Res 1975;12:189-98.

14. Sarmento ARL, Bertolucci PHF, Wajman JR. Montreal Cognitive Assessment: versão experimental brasileira. Disponível em: http://www.mocatest.org, Acesso em 4 janeiro, 2009.

15. Roth M, Tym E, Mountjoy CQ, et al. CAMDEX. A standardized instrument for the diagnosis of mental disorder in the elderly with special reference to the early detection of dementia. Br J Psychiatry 1986;149:698-709.

16. Brucki SMD, Nitrini R, Caramelli P, Bertolucci PHF, Kamoto I. Sugestões para o uso do Mini-Exame do Estado Mental no Brasil. Arq Neuropsiquiatr 2003;61:777-781.

17. Mendez MF, Ala T, Underwood K. Development of scoring criteria for the Clock Drawing Task in Alzheimer's disease. J Am Geriatr Soc 1992;40:1095-1099.

18. Yesavage JA, Brink TL, Rose TL, et al. Development and validation of geriatric depression screening scale: a preliminary report. J Psychiatric Res 1983;17:37-49.

19. American Psychiatry Association. Diagnostic and statistical manual of mental disorders, $4^{\text {th }}$ ed. Washington, DC: American Psychiatry Association; 1994.

20. Mckhann G, Drachmann D, Folstein M, et al. Clinical Diagnosis of Alzheimer's Disease: report of the NINCDS-ADRDA work group under the auspices of Department of Health and
Human Services Task Force on Alzheimer's Disease. Neurology 1984;34:939-994.

21. Dourado M, Laks J, Rocha M, et al. Consciência da doença na demência.Resultados preliminares em pacientes com doença de Alzheimer leve e moderada. Arq Neuropsiquiatr 2005;63:114-118.

22. Báez S, Mendoza L, Reyes P, et al. Interpretation of proverbs and Alzheimer's disease. Rev Neurol 2009;49:566-572.

23. Rahman TTA, Gaafary MM. Montreal Cognitive Assessment Arabic version: reliability and validity prevalence of mild cognitive impairment among elderly attending geriatric clubs in Cairo. Geriatr Gerontol Int 2009;9:54-61.

24. Brucki SMD. Does prevention for Alzheimer's disease exist? Dement Neuropsychol 2009;3:209-213.

25. Radanovic M, Carthery-Goulart MT, Charchat-Fichman H, et al. Analysis of brief language tests in the detection of cognitive decline and dementia. Dement Neuropsychol 2007;1:37-45.

26. Aprahamian I, Cecato JF, Martinelli JE, et al. Can the CAMCOG be a good cognitive test for patients with Alzheimer's disease with low educational level? Int Psychogeriatr 2010 (in press).

27. Okamoto IH, Bustamante SEZ. Testes de rastreio para o diagnóstico de demência. In: Demência e transtornos cognitivos em idosos. Bottino CMC, Laks J, Blay SL (Editors). Rio de Janeiro, Guanabara Koogan; 2006;472:77-85. 